\title{
Pengaruh Vitamin C terhadap Fragilitas Osmotik Eritrosit pada Mahasiswa Kedokteran Universitas Jember yang Mengalami Stres Psikologis
}

\author{
(Effect of Vitamin C on Osmotic Fragility of Erythrocytes in \\ Medical Students of Jember University with Psychological Stress)
}

\author{
Zulfahmi Muslim, Aris Prasetyo, Septa Surya Wahyudi \\ Fakultas Kedokteran Universitas Jember \\ JI. Kalimantan 37, Jember 68121 \\ e-mail: aprasetyo08@gmail.com
}

\begin{abstract}
Medical students are constantly getting stress that could lead to oxidative stress where the level of free radicals is higher than the level of antioxidants in the body. Free radicals can bind to erythrocyte membranes and alter membrane structure that lead to the integrity of the erythrocyte membrane resulting in decreased erythrocyte ability in preventing hemolysis. Vitamin $C$ is an antioxidant that could prevent free radicals bond to erythrocyte membrane. Vitamin $C$ works by donating electrons to free radicals and prevent binding to erythrocyte membranes. The purposed of this study was to determine the effect of vitamin C consumption on osmotic fragility of erythrocytes in medical students with psychological stress. This research was clinical trial research with quasi experimental with pretest-posttest control group design. Researchers used Depression Anxiety Stress Scale (DASS) questionnaire to measure the stress level. Data analysis using $T$ test obtained mean of percentage of hemolysis between pretest and posttest was $p=0,02$. It can be concluded that there is significant difference on osmotic fragility due to Vitamin $C$ consumption in medical Student of Jember University with psychological stress.
\end{abstract}

Keywords: Psychological Stress, Vitamin C, Osmotic Fragility of Erythrocytes

\begin{abstract}
Abstrak
Mahasiswa kedokteran terus menerus mendapatkan stresor psikologis yang dapat menimbulkan suatu keadaan stres oksidatif sehingga jumlah radikal bebas lebih tinggi dibandingkan jumlah antioksidan dalam tubuh. Radikal bebas dapat berikatan dengan membran eritrosit dan mengubah struktur membran. Hal ini menyebabkan penurunan integritas membran eritrosit sehingga terjadi penurunan kemampuan eritrosit dalam menahan terjadinya hemolisis. Vitamin $\mathrm{C}$ merupakan antioksidan dapat mencegah ikatan radikal bebas dengan membran eritrosit. Vitamin $C$ bekerja dengan mendonorkan elektron pada radikal bebas sehingga mencegah ikatan dengan membran eritrosit. Tujuan penelitian ini adalah mengetahui pengaruh konsumsi vitamin $\mathrm{C}$ terhadap fragilitas osmotik eritrosit mahasiswa kedokteran yang mengalami stres psikologis. Penelitian ini merupakan penelitian uji klinis dengan pendekatan quasi experimental dengan rancangan pretest-posttest control group design. Peneliti menggunakan kuesioner Depression Anxiety Stress Scale (DASS) untuk mengukur tingkat stres sampel. Analisis data menggunakan uji T dan didapatkan rerata persentase hemolisis antara pretest dan posttest yaitu $p=0,002$ sehingga dapat disimpulkan bahwa terdapat perbedaan yang bermakna pada fragilitas osmotik eritrosit akibat pemberian Vitamin C pada Mahasiswa FK UNEJ yang mengalami stres psikologis.
\end{abstract}

Kata kunci: Stres Psikologis, Vitamin C, Fragilitas Osmotik Eritrosit 


\section{Pendahuluan}

Stres psikologis adalah stres yang disebabkan karena gangguan situasi psikologis atau ketidakmampuan kondisi psikologis untuk menyesuaikan diri seperti hubungan interpersonal, sosial budaya, atau faktor keagamaan [1]. stres psikologis yang ditimbulkan akibat kehidupan akademik yang ketat di lingkungan mahasiswa kedokteran membawa toksisitas psychobiological tinggi yang berkontribusi dalam peningkatan stres di lingkungan mahasiswa [2]. Banyak faktor yang menyebabkan mahasiswa kedokteran mengalami stres psikologis beberapa diantaranya yaitu ketidakmampuan untuk memahami materi, tekanan menjelang ujian, berpikir negatif, takut kehilangan beasiswa, manajemen waktu yang buruk, dan kelelahan [3]. Kecemasan dari mahasiswa cenderung menyebabkan terkena stres oksidatif lebih banyak. Keadaan stres oksidatif terjadi bila jumlah radikal bebas lebih tinggi dibandingkan jumlah antioksidan dalam tubuh yang dapat menyebabkan efek toksik yang dapat mengubah struktur dan fungsi molekuler jaringan [4].

Radikal bebas atau yang dikenal juga oksigen reaktif (reactive oxygen species atau ROS) merupakan produk normal dari metabolisme sel di dalam tubuh yang dapat bermanfaat ataupun membahayakan terhadap mahluk hidup tersebut [5]. Radikal bebas memiliki satu elektron yang bebas yang tidak berpasangan dan dapat bereaksi dengan jaringan tubuh sehingga jaringan tersebut dapat mengalami kerusakan [6]. Ekinosit dapat terbentuk apabila ROS bereaksi dengan komponen asam lemak dari membran sel eritrosit sehingga terjadi reaksi crosslinking oleh spektrin yang merupakan komponen dari membran sel yang berfungsi menjaga fleksibilitas membran sel dengan hemoglobin pada eritrosit. Gangguan pada strutur spektrin menyebabkan peningkatan fragilitas membran eritrosit sehingga eritrosit mudah mengalami hemolisis [7].

Vitamin C termasuk dalam golongan antioksidan sekunder yaitu antioksidan yang berfungsi menangkap senyawa radikal serta mencegah terjadinya reaksi berantai [8]. Vitamin $C$ bekerja dengan cara mendonorkan elektron dan agen pereduksi terhadap radikal bebas agar tidak mengoksidasi senyawa lain [9]. Pada penelitian yang dilakukan oleh Adenloka menunjukkan bahwa pemberian vitamin $C$ dapat menurunkan fragilitas osmotik eritrosit [10]. Tujuan penelitian ini adalah mengetahui pengaruh konsumsi vitamin $C$ terhadap fragilitas osmotik eritrosit pada mahasiswa kedokteran yang mengalami stres psikologis.

\section{Metode Penelitian}

Penelitian ini merupakan penelitian uji klinis dengan pendekatan quasi experimental dengan rancangan pretest-posttest control group design. Sampel penelitian sebanyak 32 responden yang merupakan Mahasiswa Fakultas Kedokteran Universitas Jember (FK UNEJ). Penelitian ini telah mendapatkan persetujuan etik dengan no. 1.144/H25.1.11/KE/2017 dari Komisi Etik Penelitian Fakultas Kedokteran Universitas Jember. Penelitian dilaksanakan di Laboratorium Biokimia Fakultas Kedokteran Universitas Jember. Sampel penelitian berjumlah 32 orang berdasarkan kriteria inklusi dan eklusi. Sampel dibagi menjadi dua kelompok yaitu kelompok kontrol dan kelompok perlakuan.

Kriteria inklusi sampel penelitian Kriteria inklusi pada penelitian ini meliputi usia sukarelawan yang digunakan dalam penelitian ini adalah usia dewasa muda dari usia 18 tahun sampai dengan 25 tahun, jenis kelamin laki-laki, Indeks Masa Tubuh (IMT) yang digunakan pada penelitian ini diantara 18 hingga $26 \mathrm{~kg} / \mathrm{m} 2$, tekanan darah sistolik tidak lebih dari 140 $\mathrm{mmHg}$, tekanan darah diastolik tidak lebih dari $90 \mathrm{mmHg}$, sukarelawan dianjurkan untuk tidak melakukan olahraga berat selama 1 minggu, dan memenuhi skor DASS (skor Depression diatas 9, skor Anxiety diatas 7, atau skor Stress diatas 14). Kriteria eksklusi adalah menderita keganasan Hematologi, mengkonsumsi tablet antioksidan (vitamin C, vitamin E) secara rutin selama 1 bulan sebelum pretest dilaksanakan, mengikuti terapi relaksasi rutin selama 1 bulan sebelum pretest dilaksanakan, merokok selama 1 bulan terakhir, minum alkohol, dan mengkonsumsi obat kortikosteroid.

Sampel diambil darah pada vena mediana kubiti pada saat pretest dan posttest dilaksanakan. Kelompok perlakuan diberikan tablet vitamin C $500 \mathrm{mg}$ diberikan setelah makan dengan dosis $500 \mathrm{mg}$ per hari selama sepuluh hari.

Prosedur pengukuran fragilitas osmotik yaitu dengan menyediakan 12 buah tabung lalu dilakukan pengenceran bertingkat larutan $\mathrm{NaCl}$ dengan konsentrasi: $0,85 \%, 0,75 \%, 0,65 \%$, $0,60 \%, 0,55 \%, 0,50 \%, 0,45 \%, 0,40 \%, 0,35 \%$, $0,30 \%, \quad 0,20 \%$ dan $0,10 \%$, masing-masing sebanyak $5,0 \mathrm{ml}$. Larutan salin dibuat dari 
larutan $\mathrm{NaCl}$ 0,9\%. Selanjutnya menambahkan $0,05 \mathrm{ml}$ darah pada masing-masing tube. Kemudian meletakkan tabung pada suhu ruangan selama 30 menit kemudian disentrifuge selama 5 menit pada $3000 \mathrm{rpm}$. Lalu memindahkan supernatant ke kuvet dibaca dengan spektrofotometer pada panjang gelombang $540 \mathrm{~nm}$. Pengukuran persentase hemolisis dengan membagi absorbansi tabung yang diukur dengan absorbansi tabung ke $6(\%)$ [11].

Pada penelitian ini dilakukan uji pendahuluan sebanyak 2 kali yaitu pada kelompok kontrol dan perlakuan menggunakan prosedur Kee. Pada uji ini digunakan pengukuran secara makroskopis dengan melihat kekeruhan pada tabung yang menandakan terjadinya hemolisis eritrosit. Pada sampel satu awal hemolisis terjadi pada tabung $0,4 \%$ sedangkan pada sampel dua pada $0,5 \%$. Pada penelitian ini terdapat keterbatasan tenaga, alat, dan waktu sehingga peneliti memilih tabung yang digunakan dalam penelitian. Peneliti menentukan batas atas dan bawah tabung yaitu dengan menambah satu tabung saat mulai terjadinya hemolisis. Pada uji tersebut sampel dua mengalami hemolisis pada konsentrasi salin yang kurang hipotonis sehingga digunakan menentukan batas atas tabung dengan menambah satu tabung diatasnya yaitu $0,55 \%$. Sedangkan sampel satu mengalami hemolisis pada larutan yang lebih hipotonis sehingga digunakan untuk menentukan batas bawah tabung saat mulai hemolisis dengan menambah satu tabung dibawahnya yaitu $0,35 \%$. Selain itu tabung $0,1 \%$ digunakan sebagai tabung pembanding. Sehingga pada peneltian ini digunakan tabung dengan konsentrasi $\mathrm{NaCl}$ $0,55 \%, 0,5 \%, 0,45 \%, 0,4 \%, 0,35 \%, 0,1 \%$.

Data yang diperoleh dari penelitian ini disajikan dalam bentuk tabel. Data diuji normalitas menggunakan Shapiro Wilk dan uji homogenitas Levene test. Analisis data untuk mengetahui fragilitas osmotic pretest dan posttest menggunakan uji-T dengan tingkat pemaknaan $<0.05$. Data dalam penelitian ini diolah menggunakan program Statistical Package for Social Science (SPSS) 23.0.

\section{Hasil}

Pada penelitian ini didapatkan 32 sampel yang memenuhi kriteria inklusi dan tidak memiliki kriteria eklusi. Karakteristik sampel pada penelitian ini dapat dilihat pada Tabel 1.
Tabel. 1 Distribusi karakteristik sampel

\begin{tabular}{|c|c|c|}
\hline Variabel & Mean & $\operatorname{Sig}(p)$ \\
\hline $\begin{array}{c}\text { IMT }\left(\mathbf{k g} / \mathbf{m}^{\mathbf{2}}\right) \\
\text { Kontrol } \\
\text { Perlakuan }\end{array}$ & $\begin{array}{l}21,27 \pm 2,55 \\
20,42 \pm 2,46\end{array}$ & 0,515 \\
\hline 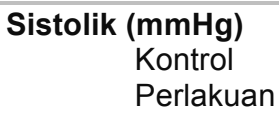 & $\begin{array}{l}113,87 \pm 4,71 \\
116,87 \pm 7,04\end{array}$ & 0,270 \\
\hline $\begin{array}{c}\text { Diastolik }(\mathrm{mmHg}) \\
\text { Kontrol } \\
\text { Perlakuan }\end{array}$ & $\begin{array}{c}78,87 \pm 5,5 \\
79,06 \pm 5,83\end{array}$ & 1,00 \\
\hline $\begin{array}{l}\text { Usia (tahun) } \\
\text { Kontrol } \\
\text { Perlakuan }\end{array}$ & $\begin{array}{l}19,44 \pm 1,365 \\
19,75 \pm 1,183\end{array}$ & 0,468 \\
\hline $\begin{array}{l}\text { Fragilitas Osmotik } \\
\text { Prestest pada } \\
\text { tabung } 0,35 \%(\%) \\
\text { Kontrol } \\
\text { Perlakuan }\end{array}$ & $\begin{array}{l}86,00 \pm 17,66 \\
91,69 \pm 19,25\end{array}$ & 0,984 \\
\hline $\begin{array}{l}\text { Fragilitas Osmotik } \\
\text { Prestest pada } \\
\text { tabung } 0,55 \%(\%) \\
\text { Kontrol } \\
\text { Perlakuan }\end{array}$ & $\begin{array}{l}8,85 \pm 3,34 \\
8,79 \pm 2,19\end{array}$ & 0,532 \\
\hline
\end{tabular}

Pada tabel 1 tidak ditemukan perbedaan signifikan pada karakteristik sampel $(p>0,05)$.

Tabel 2 Uji Paired T-test fragilitas osmotik eritrosit

\begin{tabular}{|l|c|c|c|}
\hline Variabel & $\begin{array}{c}\text { Mean } \\
(\%)\end{array}$ & SD & $\begin{array}{c}\text { T-Test } \\
\text { (sig.) }\end{array}$ \\
\hline $\begin{array}{l}\text { Perlakuan } \\
\text { tabung } \\
\mathbf{0 , 3 5 \%}\end{array}$ & & & \\
$\begin{array}{l}\text { Pretest } \\
\text { Posttest }\end{array}$ & 86,00 & $\pm 17,66$ & 0,02 \\
\hline $\begin{array}{l}\text { Kontrol } \\
\text { tabung 0,35\% }\end{array}$ & 85,93 & $\pm 12,43$ & \\
$\begin{array}{l}\text { Pretest } \\
\text { Posttest }\end{array}$ & 91,69 & $\pm 19,25$ & 0,984 \\
\hline $\begin{array}{l}\text { Perlakuan } \\
\text { tabung } \\
\text { 0,55\% } \\
\begin{array}{l}\text { Pretest } \\
\text { Posttest }\end{array}\end{array}$ & 73,88 & $\pm 15,78$ & \\
\hline $\begin{array}{l}\text { Kontrol } \\
\text { tabung 0,55\% }\end{array}$ & 6,75 & $\pm 2,19$ & 0,02 \\
\hline & & $\pm 1,96$ & \\
\hline
\end{tabular}




\begin{tabular}{|l|l|l|l|}
\hline Pretest & 8,85 & $\pm 3,34$ & 0,532 \\
Posttest & 8,48 & $\pm 2,27$ & \\
\hline
\end{tabular}

Hasil analisis uji $\mathrm{T}$ pada Tabel 2 menunjukkan tidak ada perbedaan bermakna pada kelompok kontrol baik pada tabung $0,35 \%$ dan tabung $0,55 \%(p>0,05)$. Sedangkan pada kelompok perlakuan terdapat perbedaan bermakna pada pada tabung $0,35 \%$ dan $0,55 \%$ yang diberikan vitamin $\mathrm{C}$ selama 10 hari $(p<0,05)$.

\section{Pembahasan}

Perbandingan IMT, usia, rerata fragilitas saat pretest, tekanan darah sistolik dan diastolik tidak ditemukan perbedaan yang signifikan $(p>0,05)$ antara kelompok kontrol dan perlakuan. Data tersebut menunjukkan bahwa proses randomisasi sampel efektif. Tujuan dari perbandingan tersebut yaitu mengurangi faktor perbedaan karakteristik sampel yang dapat menjadi faktor pengganggu pada penelitian sehingga diharapkan bahwa hanya pemberian perlakuan saja yang mempengaruhi hasil penelitian.

Hasil penelitian menunjukkan bahwa fragilitas osmotik eritrosit yang ditunjukkan dengan persentase hemolisis. Perhitungan persentase hemolisis didapatkan dengan cara membagi absorbansi tabung yang diukur dengan absorbansi tabung ke-6 dalam satuan $\%$. Kemudian semua data persentase hemolisis pada keenam tabung di rata-rata sehingga didapatkan nilai rerata persentase hemolisis. Pada penelitian ini digunakan tabung $0,55 \%$ dan $0,35 \%$ sebagai tabung yang dianalisis karena merupakan batas atas dan bawah dari tabung yang diteliti. Hasil dari data diatas menunjukkan bahwa rerata persentase hemolisis hemolisis kelompok kontrol saat pretest dan posttest pada tabung $0,35 \%$ sebesar $86,00 \pm 17,66 \%$ dan $85,93 \pm 12,43 \%$ sedangkan rata-rata persentase hemolisis kelompok perlakuan saat pretest dan posttest sebesar $91,69 \pm 19,25 \%$ dan $73,88 \pm 15,78 \%$. Rerata hemolisis kelompok kontrol saat pretest dan posttest pada tabung $0,55 \%$ sebesar $8,85 \pm 3,34 \%$ dan $8,48 \pm 2,27 \%$ sedangkan rata-rata persentase hemolisis kelompok perlakuan saat pretest dan posttest sebesar $8,79 \pm 2,19 \%$ dan $6,75 \pm 1,96 \%$. Nilai normal rerata persentase hemolisis untuk saat ini jarang digunakan sehingga nilai normal masih belum tersedia.

Stres psikologis seperti kecemasan, depresi, kesulitan penyesuaian, dan berbagai kondisi psikologis ditemukan pada lingkungan perkuliahan berkorelasi langsung dengan stres oksidatif yang berarti ini adalah agen yang saling berkaitan [12]. Keadaan stres oksidatif yang ditandai dengan peningkatan kadar radikal bebas dalam tubuh dan penurunan kadar antioksidan dapat menyebabkan peroksidasi lipid membran eritrosit oleh radikal bebas sehingga terjadi kerusakan membran eritrosit yang ditandai dengan peningkatan fragilitas membran eritrosit [13]. Hal ini telah dijelaskan bahwa stres psikologis dapat meningkatkan kadar radikal bebas melalui jalur epinefrin, kortisol dan juga aktivitas neurtrofil yang berlebihan. Akibatnya terbentuk radikal hidroksil yang bersifat toksik dan dapat berikatan dengan membran sel eritrosit [14].

Pada kelompok perlakuan dan kontrol saat pretest nilai rerata persentase hemolisis memiliki nilai $p>0,05$. Hal ini menunjukkan bahwa fragilitas osmotik eritrosit pada kedua kelomok sampel tidak menunjukkan perbedaan yang signifikan saat dilakukan pretest. Hal ini dapat dimungkinkan bahwa kedua kelompok menerima kadar stres psikologis yang sama pada masa perkuliahan baik dari semester satu hingga semester tujuh. Selain itu kriteria inklusi dari penelitian dapat mengurangi pengaruh faktor lain yang dapat mempengaruhi kadar radikal bebas dalam tubuh.

Perbandingan antara kelompok kontrol saat pretest dan posttest tidak menunjukkan hasil yang signifikan $p=0,984$ dan 0,532 $(p>0,05)$. Kelompok kontrol tidak mendapatkan perlakuan dengan pemberian vitamin $C$ sehingga hanya terpapar stress psikologis selama perkuliahan. Sedangkan perbandingan data pretest dan posttest pada kelompok perlakuan pada kedua tabung menunjukkan hasil yang signifikan $p=0,02 \quad(p<0,05)$. Hal ini sesuai dengan teori bahwa vitamin $C$ yang merupakan antioksidan dapat menurunkan kadar radikal bebas dalam tubuh dan menurunkan fragilitas osmotik eritrosit. Vitamin $C$ bekerja sebagai donor elektron, dengan cara memindahkan satu elektron ke senyawa radikal bebas dan mencegah peroksidasi lemak pada membran sel eritrosit. Vitamin C yang tereduksi kemudian membentuk asam dehidroaskorbat. Asam dehidroaskorbat akan dihidrolisis menjadi asam 2,3- diketoglukonat [9]. Senyawa tersebut terbentuk melalui ruptur ireversibel dari cincin lakton yang merupakan bagian dari asam askorbat, radikal askorbil, dan asam dehidroaskorbat. Asam 2,3-diketoglukonat akan dimetabolisme menjadi xilosa, xilonat, liksonat, 
dan oksalat [15]. Akibatnya dengan mekanisme tersebut integritas dari membran eritrosit dapat terjaga sehingga sesuai dengan data didapatkan penurunan fragilitas osmotik eritrosit $(p<0,05)$ pada kelompok perlakuan.

Penelitian yang dilakukan oleh Candan menunjukkan bahwa pemberian vitamin $\mathrm{C}$ pada pasien yang menjalani terapi hemodialisis akibat defisiensi zinc dapat menurunkan kadar fragilitas osmotik eritrosit dibandingkan pada kelompok plasebo [16]. Penelitian yang dilakukan oleh Brody menunjukkan bahwa pemberian vitamin $\mathrm{C}$ dengan dosis tinggi dapat menurunkan kadar kortisol darah, efek shear stress akibat tekanan darah tinggi dan memberikan respon yang lebih baik terhadap stres psikologis. Kortisol merupakan suatu jalur yang sangat penting dalam pembentukan radikal bebas [17]. Kortisol dapat meningkatkan radikal bebas melalui jalur Hipoalamus-Pituitari-Adrenal (HPA) Axis, reaksi imun dan peningkatan epinefrin [14]. Oleh karena itu penurunan jumlah kortisol akibat pemberian vitamin $C$ dapat menurunkan kadar radikal bebas dalam tubuh. Selain itu terdapat hubungan erat peningkatan kadar kortisol dikaitkan dengan depresi [18]. Orang yang mengalami stress psikologis dapat meningkatkan radikal bebas. Penelitian yang dilakukan Brody pemberian vitamin $\mathrm{C}$ juga dapat memperbaiki respon terhadap stres psikologi [17]. Hal ini memungkinkan pada kelompok perlakuan penelitian ini dapat memperbaiki respon terhadap stres psikologis pada masa perkuliahan dan mencegah produksi radikal bebas. Kelemahan pada penelitian ini yaitu prosedur pengukuran frragilitas osmotic dilakukan secara modifikasi. Selain itu pengukuran kadar stres sampel bersifat subjektif sehingga dapat mempengaruhi penelitian.

\section{Simpulan dan Saran}

Terdapat pengaruh yang bermakna pemberian vitamin $\mathrm{C}$ terhadap fragilitas osmotik eritrosit pada mahasiswa FK UNEJ pada kelompok perlakuan dengan $p$-value sebesar $0,02(p<0,05)$.

\section{Daftar Pustaka}

[1] Kawuryan F. Tinjauan faktor-faktor psikologis dan sosial dalam mempengaruhi stres. Jurnal Mawas.2009;1:1.

[2] Aguiar SM, Vieira KM, Vieira SM, Aguiar, dan Nóbrega JO. Prevalence of stres symptoms among medical students.
Jornal Brasileiro de Psiquiatria. 2009;58(1): 34-38.

[3] Kulsoom B, Afsar NA. Stress, anxiety, and depression among medical students in a multiethnic setting. Neuropsychiatric disease and treatment. 2015; 11: 1713.

[4] Matsushita MG, Kumano N. Suganuma $H$, Adachi S, Yamamura SH, Morishima Y, Shigedo A, Mikami M, Takeda, Sugita. Anxiety, neuroticism and oxidative students: Cross-sectional study in nonsmoking college students.Psychiatry and clinical neurosciences. 2010;64(4): 435441.

[5] Valko M, Rhodes, J, Moncol MM, Izakovic, Mazur M. Free radicals, metals and antioxidants in oxidative stresinduced cancer. Chemico-biological interactions. 2006; 160: 1-40.

[6] Halliwell B, Gutteridge JM. 2007. Free Radicals in Biology and Medicine.

[7] Chiu D, Lubin, B, Dan SB, Shohet. 1982. Peroxidative reactions in red cell biology. Free Radicals in Biology. 5: 115-160.

[8] Gordon L. Functional Food, Food Design, Pharmafood. New York: Champman dan Hall. 1994.

[9] Padayatty SJ, Katz A, Wang Y, Eck, Kwon O, Lee JH, Chen S, Corpe C, Dutta SK, Levine M. 2003. Vitamin C as an antioxidant: evaluation of its role in disease prevention. 2003; 22(1): 18-35.

[10] Adenkola AY, Adah AS, Ambali SF. The effects of vitamins $C$ and e on erythrocyte osmotic fragility, serum malondialdehyde concentrations and surface erythrocyte sialic acid in rams following road transportation. Alexandria Journal for Veterinary Sciences. 2016; 48:2.

[11] Kee JL. Pedoman Pemeriksaan Laboratorium dan Diagnostik. Jakarta: EGC. 2007.

[12] Srivastava R, Dan J, Batra. Oxidative stres and psychological functioning among medical students. Industrial Psychiatry Journal. 2014; 23: 127.

[13] Srour MA, Bilto YY, Juma M, Irhimeh MR. Exposure of human erythrocytes to oxygen radicals causes loss of deformability, increased osmotic fragility, lipid peroxidation and protein degradation. Clinical hemorheology and microcirculation. 2000;23: 13-21.

[14] Spiers JG, Chen HJ, Sernia C, Lavidis NA. Activation of the hypothalamic-pituitaryadrenal stress axis induces cellular 
Muslim, et al., Pengaruh Vitamin C terhadap Fragilitas Osmotik Eritrosit pada Mahasiswa .....

oxidative stress. Frontiers in Neuroscience. 2015; 8: 456.

[15] Sharma P, Dubey SR. Involvement of oxidative stres and role of antioxidative defense system in growing rice seedlings exposed to toxic concentrations of aluminum. Plant cell reports. 2007;26(11): 2027-2038.

[16] Candan F, Gültekin F. Effect of vitamin C and zinc on osmotic fragility and lipid peroxidation in zinc-deficient haemodialysis patients. 2002; 20(2): 95-
98.

[17] Brody SR, Preut K, Schommer, Schürmeyer TH. A randomized controlled trial of high dose ascorbic acid for reduction of blood pressure, cortisol, and subjective responses to psychological stress. 2002;159(3): 319-324.

[18] Plotsky PM, Owens MJ, Nemeroff CB. Psychoneuroendocrinology of depression. Hypothalamic-pituitary-adrenal axis. Psychiatry Clinic. 1998; 21: 293-307. 